\title{
Phytochemical analysis, antioxidant and in vitro $\beta$-galactosidase inhibition activities of Juniperus phoenicea and Calicotome villosa methanolic extracts
}

\author{
Ahmed Al-Mustafa ${ }^{1 *}(\mathbb{0}$, Mohammad Al-Tawarah', Mohammed Sharif Al-Sheraideh² and \\ Fatema Attia Al-Zahrany²
}

\begin{abstract}
Background: Juniperus Phoenicea (JP) and Calicotome Villosa (CV) are used by Jordanian populations as herbal remedies in traditional medicine. Herein, the phytochemical contents of their methanolic extracts were analyzed and their antioxidant as well as in vitro anti- $\beta$-Galactosidase activities were evaluated; their effect on $\beta$-Galactosidase enzyme kinetics was evaluated and the thermodynamic of the enzyme was determined.

Methods: The antioxidant activity of JP and CV crude methanolic extracts was evaluated using 1,1-diphenyl,2picrylhydrazyl (DPPH) free radical scavenging and ferric reducing antioxidant power (FRAP) assays; however, the effect of the plants' crude extracts on $\beta$-Galactosidase activity and kinetics was evaluated in vitro. Moreover, total phenolic, flavonoids, and flavonols content in plants' extracts were determined and expressed in Gallic acid equivalent (mg GAE/g dry extract) or rutin equivalent (mg RE/g dry extract).

Results: Phytochemical screening of the crude extracts of JP and CV leaves revealed the presence of phenols, alkaloids, flavonoids, terpenoids, anthraquinones, and glycosides. Flavonoids and flavonols contents were significantly higher in JP than in CV $(p<0.05)$. Furthermore, an analogous phenolic content was detected in both JP and CV methanolic extracts (103.6 vs $99.1 \mathrm{mg}$ GAE/g extract). The ability of JP extract to scavenge DPPH radicals was significantly higher than that of $C V$ extract with $I_{50}=11.1 \mu \mathrm{g} / \mathrm{ml}$ and $15.6 \mu \mathrm{g} / \mathrm{ml}$, respectively. However, their extracts revealed relatively similar antioxidant capacities in FRAP assay; their activity was concentration dependent. The JP extract inhibited $\beta$-galactosidase enzyme activity with a significant $I C_{50}$ value compared to $C V$ extract; they exhibited their inhibitory activities at $I C_{50}$ values $65 \mu \mathrm{g} / \mathrm{ml}$ and $700 \mu \mathrm{g} / \mathrm{ml}$, respectively. Rutin revealed anti- $\beta$-galactosidase activity at $\mathrm{IC}_{50}=75 \mu \mathrm{g} / \mathrm{ml}$. The mode of inhibition of $\beta$-galactosidase by JP, CV, and rutin was non-competitive, mixed, and competitive inhibition, respectively. Thermodynamic and enzyme inactivation kinetics revealed that $\beta$-galactosidase has a half-life time of $108 \mathrm{~min}$ at $55^{\circ} \mathrm{C}$, activation energy of $208.88 \mathrm{~kJ} \mathrm{~mol}^{-1}$ and the inactivation kinetics follows a first-order reaction with k-values $0.0023-0.0862 \mathrm{~min}^{-1}$ and positive entropy of inactivation $\left(\Delta S^{\circ}\right)$ values at various temperatures, indicating non-significant processes of aggregation.
\end{abstract}

\footnotetext{
*Correspondence: ahmedh65@mutah.edu.jo

${ }^{1}$ Department of Biological Sciences, Faculty of Science, Mutah University,

Mutah, P.O. Box 7, Karak 61710, Jordan

Full list of author information is available at the end of the article
} original author(s) and the source, provide a link to the Creative Commons licence, and indicate if changes were made. The images or other third party material in this article are included in the article's Creative Commons licence, unless indicated otherwise in a credit line to the material. If material is not included in the article's Creative Commons licence and your intended use is not permitted by statutory regulation or exceeds the permitted use, you will need to obtain permission directly from the copyright holder. To view a copy of this licence, visit http://creativecommons.org/licenses/by/4.0/. The Creative Commons Public Domain Dedication waiver (http://creativeco mmons.org/publicdomain/zero/1.0/) applies to the data made available in this article, unless otherwise stated in a credit line to the data. 
Conclusions: The methanolic extracts of JP and CV possess anti-hyperglycemic and antioxidant activities with potential pharmaceutical applications.

\section{Introduction}

Medicinal plants are used traditionally in developing countries as therapeutic agents in the treatment of chronic diseases [1]. They are one of the main sources of phytochemicals, like polyphenols, that have numerous pharmacological advantages as antioxidant, antiviral, anticancer, antimicrobial, antifungal, and antidiabetic remedies [2-6]. Jordan is a country with species richness and diversity of medicinal plants that are used in traditional medicine regardless of the economic or educational levels of the patients [7].

Juniperus phoenicea L. (JP), family Cupressaceae, is a shrub or a small tree growing in the coastal sites of the Mediterranean Region, in some Middle East countries, widely distributed in Europe, northern Africa, and the Canary Islands [8]. In Jordan, it is distributed throughout the South Mountain regions, in Tafileh and Shoubak woodlands at high altitudes of 1200-1700 $\mathrm{m}$ [9]. The leaves of JP are used in the form of decoction to treat diabetes, diarrhea, rheumatism, and as a diuretic against bronchopulmonary disease but a mixture of its leaves and berries is used as an oral hypoglycaemic agent $[6,7]$. Abu-Darwish et al. [10] reported that the essential oils of JP, collected from the South of Jordan, are characterized by a high percentage of $\alpha$-pinene content. Furthermore, the flavonoids myricitrin, quercetin, cosmosin, and quercitrin in addition to sterols, and hydrocarbons were isolated from the leaves of Egyptian JP [4, 11]. In fact, essential oils and extracts of JP were reported as antioxidants and antimicrobial agents [11-13]. Their hypoglycaemic and hypolipidemic effects as well as cytotoxic activity were also investigated [14-17].

However, Calicotome villosa (Poir.) Link subspecies intermedia, family Fabaceae, is a thorny shrub that can reach $2 \mathrm{~m}$ in height and has sharp terminations, trifoliate including oval leaves with yellow and grouped flowers [18]. It grows mostly in cool places and is very common in North Africa (Morocco and Algeria) and Spain [19]. The plant has been used in traditional medicine by Mediterranean populations for the treatment of furuncle, cutaneous abscess, chilblain, and as an antitumor agent [20-22]. The bioactivities of CV plant extracts were ascribed to their content of flavone glucosides, alkaloids, and anthraquinones in the aerial parts $[18,23,24]$ as well as flavonols and alkaloids in the seeds [25].

Diabetes mellitus is one of the most common metabolic disorders due to lack of insulin production or the inability to control blood glucose by insulin leading to hyperglycemia [26]. Therefore, inhibition of $\beta$-galactosidase, an enzyme that hydrolyze glycosidic bonds in complex carbohydrates or glycoconjugates, influences glucose uptake by the cells and is a target for regulation of hyperglycemia [27]. Interestingly, the activity and thermal stability of $\beta$-galactosidase enzymes are influenced by diverse environmental factors (temperature, $\mathrm{pH}$, and reaction medium) which can strongly affect the specific three-dimensional structure or spatial conformation of the protein [28], thereby will affect the enzyme's physiological function. Several biotechnological approaches were used to study enzyme deactivation, which forms a major and important constraint in estimation of the enzymes' thermodynamic parameters; this will lead to understanding the probable denaturation mechanism in enzymatic processes [29].

The current study aimed to analyze the phytochemical content of JP and CV methanolic extracts with evaluating their antioxidant and anti- $\beta$-Galactosidase activates as well as their role in kinetic and thermodynamic parameters of the enzyme.

\section{Materials and methods \\ Chemicals}

$\beta$-Galactosidase from Aspergillus oryzae (CAS Number: 9031-11-2), Folin-Ciocalteu phenol, 2,4,6-tripyridyl-striazine (TPTZ), 2, 2-diphenyl-2-picrylhydrazyl (DPPH), Rutin and Gallic acid were obtained from Sigma-Aldrich. $o$-Nitrophenyl- $\beta$-D-Galactopyranoside (CAS Number: 369-07-3) was obtained from ACROS ORGANICS. Other chemicals and solvents were used of analytical grade.

\section{Plant material collection and extraction}

$\mathrm{JP}$ and $\mathrm{CV}$ fresh leaves were collected in April from Al-Shoubak region in the southern part of Jordan $\left(30^{\circ} 31^{\prime} 4.52^{\prime \prime} \mathrm{N}, 35^{\circ} 33^{\prime} 25.59^{\prime \prime} \mathrm{E}\right)$. The plants' samples were identified morphologically by a plant specialist in the Department of Biology, Faculty of Sciences/University of Mutah. Voucher specimens were kept at the Laboratory of plant science, Department of Biology/Mutah University.

The extracts were prepared according to [30] with some modifications. The JP and CV leaves were air-dried in shade and $(30 \mathrm{~g})$ of the pulverized plant samples were extracted in $300 \mathrm{ml}$ of methanol (99\%) for $48 \mathrm{~h}$ under continuous shaking. The resulting extracts were filtered through a Whatman paper (No. 4) and concentrated in 
vacuum at $40{ }^{\circ} \mathrm{C}$ using a rotary evaporator (Buchi R-215, Switzerland). The methanol extracts were kept at $4{ }^{\circ} \mathrm{C}$ in the dark until further use.

\section{Phytochemical screening Qualitative analysis}

The qualitative tests of extracts' phytochemical constituent were carried out according to [31,32]; it based on the observed visual color change of methanol extracts of JP and $\mathrm{CV}$ with added reagents. The analysis was performed to detect presence of alkaloids, flavonoids, saponins, terpenoids, phenols, anthraquinones, tannins, glycosides, and anthocyanins in plants' extracts. The results are expressed as $(+)$ for the presence and (-) for the absence of phytochemicals.

\section{Quantitative analysis}

Determination of total phenols The total phenolic content of JP and CV was assayed using the Folin-Ciocalteu reagent with gallic acid as a standard [33]. $0.2 \mathrm{~mL}$ of $(10 \mathrm{mg} / \mathrm{ml})$ extract was mixed with Folin-Ciocalteu phenol reagent $(1.5 \mathrm{~mL})$. After $5 \mathrm{~min}, 6 \%$ sodium carbonate $(1.5 \mathrm{~mL})$ was added, and the mixture was allowed to stand at room temperature for $90 \mathrm{~min}$. The absorbance was measured at $725 \mathrm{~nm}$ and the results were expressed as $\mathrm{mg}$ of gallic acid equivalent per gram of extract (mg GAE/g). The assays were performed in triplicates.

Determination of total flavonoids The total flavonoid content in plant methanolic extract was estimated according to [34] with some modifications. $1 \mathrm{ml}$ of tested extract $(10 \mathrm{mg} / \mathrm{ml})$ was added to a volumetric flask containing $4 \mathrm{ml}$ of distilled water. $0.3 \mathrm{ml}$ of $5 \% \mathrm{NaNO}_{2}$ solution was added to the preparation which left for $6 \mathrm{~min}$, then $0.3 \mathrm{ml}$ of $10 \% \mathrm{AlCl}_{3}$ solution was added and kept for another $6 \mathrm{~min}$. To this reaction mixture, $4 \mathrm{ml}$ of $1 \mathrm{M}$ $\mathrm{NaOH}$ solution and $0.4 \mathrm{ml}$ water were added to make up a final volume of $10 \mathrm{ml}$. The reaction mixture was mixed well and allowed to stand for $15 \mathrm{~min}$, after which absorbance was recorded at $510 \mathrm{~nm}$. Total flavonoid content was expressed as mg rutin equivalent (RE)/g plant sample. Tests were performed in triplicates.

Determination of total flavonols The total flavonols contents of plants extracts were determined following the procedure reported by Abdel-Hameed [35] using rutin as a standard. Briefly, $0.5 \mathrm{ml}$ of methanolic plant extract $(10 \mathrm{mg} / \mathrm{ml})$ was mixed with $0.5 \mathrm{ml}(20 \mathrm{mg} / \mathrm{ml}) \mathrm{AlCl}_{3}$ and $1.5 \mathrm{ml}(50 \mathrm{mg} / \mathrm{ml})$ sodium acetate. After $2.5 \mathrm{~h}$ on incubation at $25^{\circ} \mathrm{C}$, the absorbance of the reaction was measured at $440 \mathrm{~nm}$ (UV/VIS Spectrophotometer, Novaspec Model 80-2088-64, Pharmacia Bio-tech, UK). Triplicate determinations were carried out.

\section{Antioxidant activity}

\section{Determination of DPPH radical scavenging activity}

The free radical scavenging capacity of extracts was determined using the method described by Deng et al. [36] with gallic acid as a reference. Briefly, $50 \mu \mathrm{l}$ of each extract was added to $950 \mu \mathrm{L}$ of methanolic DPPH solution $\left(\mathrm{A}_{517 \mathrm{~nm}} 0.74\right)$. The preparations were incubated for $30 \mathrm{~min}$ at room temperature in dark and their absorbance was measured at $517 \mathrm{~nm}$. Antioxidant activity of the plant extracts was calculated as follows:

$$
\mathrm{I}(\%)=\left(\left(\mathrm{A}_{\text {blank }}-\mathrm{A}_{\text {sample }}\right) / \mathrm{A}_{\text {blank }}\right) \times 100
$$

where I inhibition in DPPH absorbance, $A_{\text {blank }}$ is the absorbance of the control reaction (containing all reagents except the plant extract), and $\mathrm{A}_{\text {sample }}$ is the absorbance of the tested plant extract. Extract concentrations providing $50 \%$ inhibition $\left(\mathrm{IC}_{50}\right)$ are calculated from the plot of inhibition (\%) against extract concentration and compared with the $\mathrm{IC}_{50}$ of Gallic acid tested following the same procedure. Samples were carried out in triplicates.

\section{Ferric Reducing Antioxidant Power (FRAP) Assay}

Ferric reducing antioxidant power of methanolic extracts of plants was performed as described previously [37]. In the FRAP assay, $300 \mathrm{mM}$ acetate buffer, $\mathrm{pH} 3.6,20 \mathrm{mM}$ ferric chloride and $10 \mathrm{mM}$ 2,4,6-tripyridyl-s-triazine (TPTZ) were dissolved in $40 \mathrm{mM} \mathrm{HCl}$ (10:1:1 ratio). $0.1 \mathrm{ml}$ of different plant extract concentrations was added to $0.9 \mathrm{ml}$ of FRAP working reagent to have a final concentration of $5,10,15,20$, and $25 \mu \mathrm{g} / \mathrm{ml}$. The absorbance of the reaction mixture was measured at $593 \mathrm{~nm}$ after 10 min of incubation at $37^{\circ} \mathrm{C}$. $\mathrm{FeSO}_{4} \cdot 7 \mathrm{H}_{2} \mathrm{O}(20 \mathrm{mM})$ was used for establishing the calibration curve. The change in absorbance was calculated as FRAP value $(\mu \mathrm{M})$ by relating the ratio of $A_{593 \mathrm{~nm}}$ of the test sample to that of the standard solution of known FRAP value $(100 \mu \mathrm{M})$ using the following Equation.

$\mathrm{FRAP}=\left(\mathrm{A}_{593 \mathrm{~nm}}\right.$ test sample $/ \mathrm{A}_{593 \mathrm{~nm}}$ test standard $)$ FRAP value of standard $(\mu \mathrm{M})$.

\section{$\beta$-Galactosidase activity assay}

The $\beta$-galactosidase activity was measured as described by [38] with slight modification. 2-Nitrophenyl- $\beta$-DGalactopyranoside (ONPG) was used as a substrate, which is hydrolyzed by $\beta-$ Galactosidase to release 2-nitrophenyl (a colored agent, $\lambda \max 410 \mathrm{~nm}$ ). The reaction mixtures contained $20 \mu$ mole of ONPG dissolved in $4 \mathrm{ml}$ of $0.1 \mathrm{M}$ citrate-phosphate buffer ( $\mathrm{pH} 4.5)$ and $40 \mu \mathrm{l}$ of $\beta$-Galactosidase solution $(0.2 \mathrm{U} / \mathrm{mL})$. After incubation for $20 \mathrm{~min}$ at $30^{\circ} \mathrm{C}$, the reaction was stopped by adding $1 \mathrm{ml}$ of $1 \mathrm{M} \mathrm{Na}_{2} \mathrm{CO}_{3}$. The absorbance of the resulting 
product was measured at $420 \mathrm{~nm}$. One unit of enzyme activity was defined as the amount of enzyme which liberated $1 \mu$ mole of O-Nitrophenol per minute under assay conditions.

\section{Determination of enzyme kinetics}

To investigate the kinetics of the reaction catalyzed by $\beta$-galactosidase, the reaction velocity versus different substrate concentrations was studied according to [39]. The double reciprocal linear plot was applied to determine $V_{\max }, K_{M}$ and to estimate reaction constants. Ki calculation depends on the mode of inhibition by comparing the "apparent" values of $V_{\max }$ and $\mathrm{K}_{\mathrm{m}}$ for an enzyme in the presence and absence of an inhibitor.

\section{Determination of $\beta$-Galactosidase relative activity (\%)}

The effect of JP and CV methanolic extracts as well as rutin, at different concentrations $(16-800 \mu \mathrm{g} / \mathrm{ml})$, on $\beta$-galactosidase activity was determined according to a standard assay test [38]. The relative activity (\%) of the $\beta$-galactosidase was related to enzyme activity in absence of the effectors according to the following formula:

\section{Effect of reference sugars on $\beta$-galactosidase activity}

The effect of glucose, galactose, fructose, and acarbose on $\beta$-galactosidase activity was evaluated at different concentrations that range from $80 \mu \mathrm{g} / \mathrm{ml}$ to $4000 \mu \mathrm{g} / \mathrm{ml}$ using
Table 1 Screening of phytochemicals in J. phoenicea and C. villosa leaves methanolic extract

\begin{tabular}{llll}
\hline No & Phytochemicals & J.phoenicea & C. villosa \\
\hline 1 & Alkaloids & + & + \\
2 & Anthocyanins & + & + \\
3 & Flavonoids & + & + \\
4 & Phenols & + & + \\
5 & Saponins & + & + \\
6 & Tannins & + & + \\
7 & Terpenoids & + & + \\
8 & Glycosides & + & + \\
9 & Anthraquinons & + & + \\
\hline
\end{tabular}

Table 2 Total phenolic, flavonoids, and flavonols contents in J. phoenicea and C. villosa leaves methanol extracts

\begin{tabular}{llll}
\hline Extract & $\begin{array}{l}\text { Total phenols } \\
\text { (mg GAE/g } \\
\text { extract) }\end{array}$ & $\begin{array}{l}\text { Total flavonoids } \\
\text { (mg RE/g extract) }\end{array}$ & $\begin{array}{l}\text { Total flavonols } \\
\text { (mg RE/g } \\
\text { extract) }\end{array}$ \\
\hline J.phoenicea & $103.6 \pm 0.006^{\mathrm{a}}$ & $101.1 \pm 0.016^{\mathrm{b}}$ & $30.7 \pm 0.082^{\mathrm{d}}$ \\
C.villosa & $99.1 \pm 0.013^{\mathrm{a}}$ & $61.6 \pm 0.0075^{\mathrm{c}}$ & $19.2 \pm 0.088^{\mathrm{d}}$
\end{tabular}

Result expressed as mean $\pm S D$ of $n=3$. Values in the same column with different letters are statistically significant at $p<0.05$

Relative Activity $(\%)=[($ Enzyme activity without - Enzyme activity with extracts $) /$ Enzyme activity without $] \times 100$

ONPG as a substrate and under the same conditions used to study the enzyme activity.

\section{Thermal $\beta$-galactosidase inactivation studies}

The thermal inactivation of $\beta$-galactosidase was determined at different time intervals and incubation temperatures. The enzyme solution was incubated in sealed tubes at $50,55,60$, and $65^{\circ} \mathrm{C}$ for $3 \mathrm{~h}$ in a thermostatically controlled water bath. One tube of $\beta$-galactosidase was withdrawn at each time interval, immediately immersed in an ice bath and enzyme activity was determined as described earlier. The activity after $1 \mathrm{~min}$ of heating-up time $(t=0)$ was the initial activity, thereby eliminating the effects of heating-up.

\section{Estimation of $\beta$-galactosidase kinetic and thermodynamic parameters}

It is generally accepted that the thermal inactivation of several enzymes including $\beta$-galactosidase is a first-order reaction, and the reaction occurs at one inactivation rate
( $k$-value) in a single step, therefore kinetic and thermodynamic parameters were determined as described in previous studies $[29,39]$.

\section{Statistical analysis}

Results are expressed as a mean \pm standard deviation. Differences between the means were determined by one-way analysis of variance (one-way ANOVA). A difference in the mean values of $p<0.05$ was considered statistically significant. Also, $\mathrm{IC}_{50}$ values were determined using a nonlinear regression curve with the Microsoft Excel 2016.

\section{Results}

\section{Extract yield and phytochemical screening}

The total yields of JP and CV leaves methanol extracts were 22.83 and $14.37 \%(\mathrm{w} / \mathrm{w})$, respectively. Their leaves' extracts contained various secondary metabolites such as phenols, alkaloids, flavonoids, terpenoids, anthraquinones, and glycosides (Table 1). Furthermore, 
Table 3 DPPH antioxidant activity of J. phoenicea and C. villosa leaves methanolic extracts

\begin{tabular}{ll}
\hline Extract & $\begin{array}{l}\text { DPPH radical } \\
\text { scavenging } \\
\text { activity } \\
\left.\mathbf{( I C}_{\mathbf{5 0}}=\boldsymbol{\mu g} / \mathbf{m l}\right)\end{array}$ \\
\hline J.phoenicea & $11.10 \pm 0.015^{\mathrm{a}}$ \\
C.villosa & $15.6 \pm 0.019^{\mathrm{b}}$ \\
Gallic acid & $1.32 \pm 0.011^{\mathrm{c}}$ \\
\hline
\end{tabular}

Result expressed as mean $I_{50}$ values \pm SD from three independent experiments. Values with different letter are significantly different compared to control $(P<0.05)$

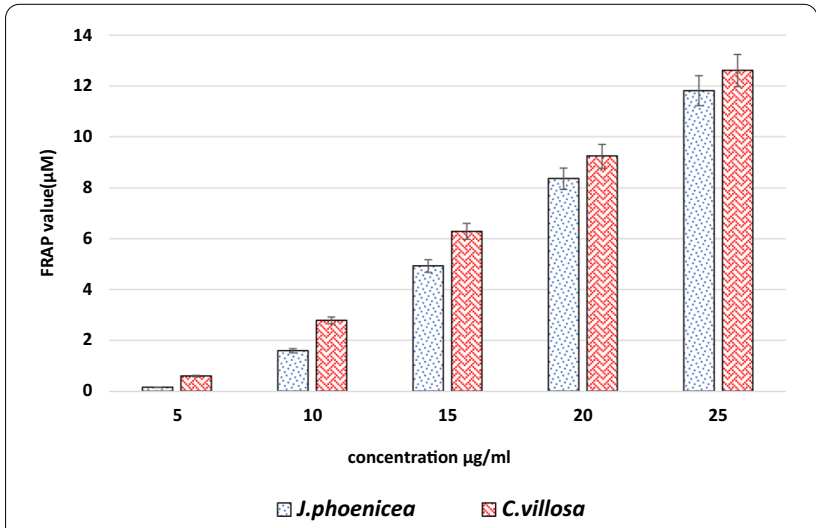

Fig. 1 FRAP value of J. phoenicea and C. villosa extracts. Each value represent means $\pm S D(n=3)$

the total phenolic, flavonoids, and flavonols contents in JP extract were $103.6 \mathrm{mg} \mathrm{GAE} / \mathrm{g}, 101.1 \mathrm{mg} \mathrm{RE} / \mathrm{g}$, and $30.7 \mathrm{mg} \mathrm{RE} / \mathrm{g}$ ), respectively; meanwhile, they were $99.1 \mathrm{mg} \mathrm{GAE} / \mathrm{g}, 61.6 \mathrm{mg} \mathrm{RE} / \mathrm{g}$, and $19.2 \mathrm{mg} \mathrm{RE} / \mathrm{g}$ in case of CV extract, respectively (Table 2 ). The flavonoids and flavonols contents were significantly higher in JP crude extract compared to CV extract $\left(\mathrm{p}^{<} 0.05\right)$.

\section{Antioxidant activity}

Evaluating the ability of tested crude extracts and the gallic acid standard at $(2 \mu \mathrm{g} / \mathrm{ml})$ to scavenge generated DPPH radical revealed percentage of inhibitions about $62.41 \%, 10 \%$, and $8.28 \%$, respectively. The order of antioxidant potency was Gallic acid $<\mathrm{JP}<\mathrm{CV}$ and in a concentration dependent manner. The $\mathrm{IC}_{50}$ values for JP, CV and gallic acid in DPPH assay were $11.1 \mu \mathrm{g} /$ $\mathrm{ml}, 15.6 \mu \mathrm{g} / \mathrm{ml}$, and $1.3 \mu \mathrm{g} / \mathrm{ml}$, respectively; they were interpreted from extrapolated regression curve of \% inhibition in DPPH radical against used sample concentrations (Table 3 ).

Furthermore, the effect of plants' extracts on ferric ion reduction in FRAP test as indication of their antioxidant potential revealed that both extracts are considered as primary antioxidant agents with non-significant differences in their effect at tested concentrations, represented by their FRAP values $(\mu \mathrm{M})$ (Fig. 1). Their effect in ferric ion reduction was concentration dependent with a positive correlation between ferric reducing capacity and the concentration of plant extract, JP $\left(R^{2}=0.9954\right)$ and $C V\left(R^{2}=0.9825\right)$.

\section{Determination of enzyme kinetics}

Determination of the $\beta$-galactosidase, from Aspergillus oryzae, enzyme kinetics was interpreted based on its ability to hydrolyze ONPG substrate at $\mathrm{pH} 4.5$ and $30^{\circ} \mathrm{C}$. The enzyme's kinetic parameters $\mathrm{Km}$ and Vmax were obtained by a typical double reciprocal Lineweaver Burk plot (Fig. 2) which were $1.310 \pm 0.091 \mathrm{mM}$ and $85.344 \pm 0.028 \mathrm{mU}$, respectively.

\section{Effect of J. Phoenicea, and C. villosa on $\beta$-Galactosidase Activity}

The effect of JP and CV on the activity of $\beta$-galactosidase was determined by performing the standard assay procedure at different concentrations from $16 \mu \mathrm{g} / \mathrm{ml}$ to $800 \mu \mathrm{g} /$ $\mathrm{ml}$. The enzymatic activity was gradually decreased with increasing concentrations. Results of the percentage of relative activity (\%) for the $\beta$-galactosidase in the presence of JP, CV, and rutin are shown in Fig. 3. JP extract inhibited $\beta$-galactosidase in a non-competitive way while that of $\mathrm{CV}$ extract was in mixed-inhibitory manner with $\mathrm{IC}_{50}$ values of 65 and $700 \mu \mathrm{g} / \mathrm{ml}$, respectively (Fig. 4). Their effect on the kinetic parameters (Vmax, Km, and $\mathrm{Ki})$ of $\beta$-galactosidase are shown in (Table 4).

\section{Effect of reference sugars on $\beta$-galactosidase activity}

The $\beta$-galactosidase activity in term of hydrolysis rate to the used ONPG substrate indicated a significant enhancement in enzyme activity in presence of glucose at concentrations over $1500 \mu \mathrm{g} / \mathrm{ml}$, while the enzyme activity was inhibited significantly in the presence of galactose; a gradual decreased in the enzyme activity $(23 \%$, $39 \%$, and $63 \%$ ) was noticed at $80 \mu \mathrm{g} / \mathrm{ml}, 400 \mu \mathrm{g} / \mathrm{ml}$, and $800 \mu \mathrm{g} / \mathrm{ml}$ of galactose, respectively. However, fructose and acarbose did not affect $\beta$-galactosidase at concentrations up to $4000 \mu \mathrm{g} / \mathrm{ml}$ (Fig. 5).

\section{Thermodynamic analysis for $\beta$-Galactosidase thermal inactivation}

The experimental enzyme inactivation was performed at $5{ }^{\circ} \mathrm{C}$ temperature intervals $\left(50,55,60\right.$, and $\left.65^{\circ} \mathrm{C}\right)$. The best fit of data is obtained when $\mathrm{Ed}=208.88 \mathrm{~kJ} \mathrm{~mol}^{-1}$. The rate constant $(\mathrm{kd})$ of $\beta$-galactosidase inactivation obtained are presented in Table 5; they were calculated from the plot of semi-natural logarithmic curve of 


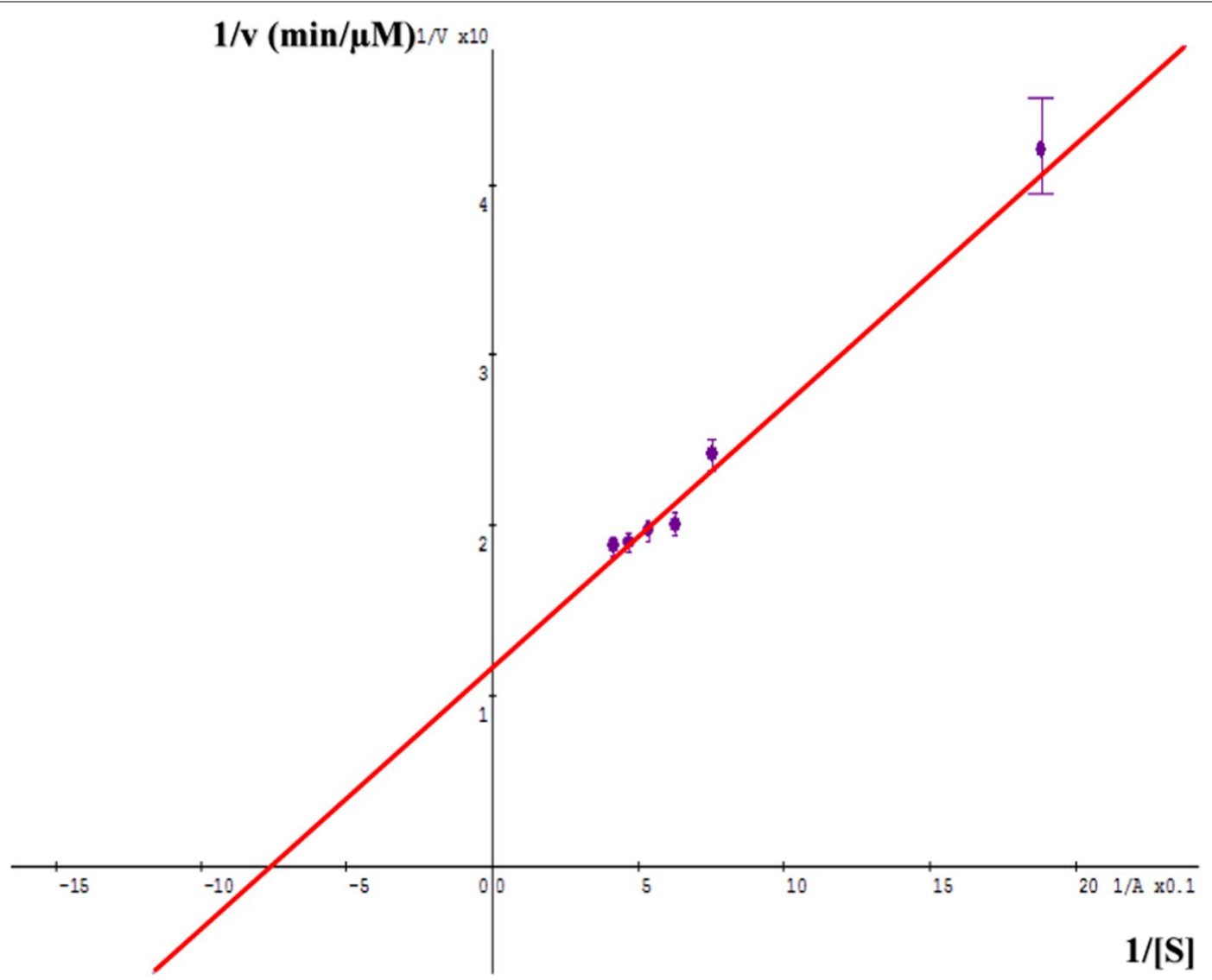

Fig. 2 Lineweaver-Burk plot of (1/v) of $\beta$-galactosidase vs (1/ ONPG). Mean $\pm S D(n=3)$

residual activity versus time (Fig. 6). Similarly, the halflife $\left(t_{1 / 2}\right)$ for the enzyme to lose its $50 \%$ activity was estimated using the equation:

$$
\mathrm{t}_{1 / 2}=0.693 / \mathrm{Kd}
$$

Moreover, the plot of half-life in minutes is expressed as a function of temperature as represent in Fig. 7. Also, the $\mathrm{D}$ value was calculated using the relationship $=\ln _{10} /$ $\mathrm{Kd}$, and the $\mathrm{z}$ value was calculated and reported to be equal to $10^{\circ} \mathrm{C}$.

Table (5) shows the thermodynamic parameters of the enthalpy of denaturation $\left(\Delta \mathrm{H}^{\circ}\right)$ for the enzyme at 50 to $65{ }^{\circ} \mathrm{C}$, which were in a range of 121.84 to $121.72 \mathrm{~kJ} / \mathrm{mol}$. There was a decreasing trend with the increase in temperature. The free energy of thermal denaturation $\left(\Delta G^{\circ}\right)$ for $\beta$-galactosidase was $91.025 \mathrm{~kJ} / \mathrm{mol}$ at $50{ }^{\circ} \mathrm{C}$, which decreased with the increase in temperature to $85.068 \mathrm{~kJ} /$ $\mathrm{mol}$ at $65{ }^{\circ} \mathrm{C}$. While the calculated entropy of inactivation $\left(\Delta S^{\circ}\right)$ showed positive values at each experimental temperature, which indicates that there are no significant processes of aggregation; otherwise if this had been happened, the values of $\left(\Delta S^{\circ}\right)$ would have been negative.

\section{Discussion}

Natural products obtained from the medicinal plants encompass complex phytochemicals that are applied in several medical applications as anticancer, antidiabetic, and antioxidant agents. Furthermore, these chemicals are used in food industry and biotechnology due to their polyphenolic content [40-44]. Previous research, describe the potential use of Juniper species as sources of secondary metabolites, as antioxidant [45], antimicrobial $[15,16]$ or hypoglycaemic and hypolipidemic agents [46].

In this study, the qualitative and quantitative evaluation of the phytochemical constituents of JP and CV leaves extracts approved the presence of various secondary metabolites such as alkaloids, glycosides, polyphenols, saponins, terpenes, and anthraquinones, which confirms the medicinal importance of these plants. This finding is in accord with previous works $[6,18]$. The methanol was used to extract secondary metabolites in JP and CV because of its capability to extract polar as well as nonpolar molecules and as recommended by [6]. This result 


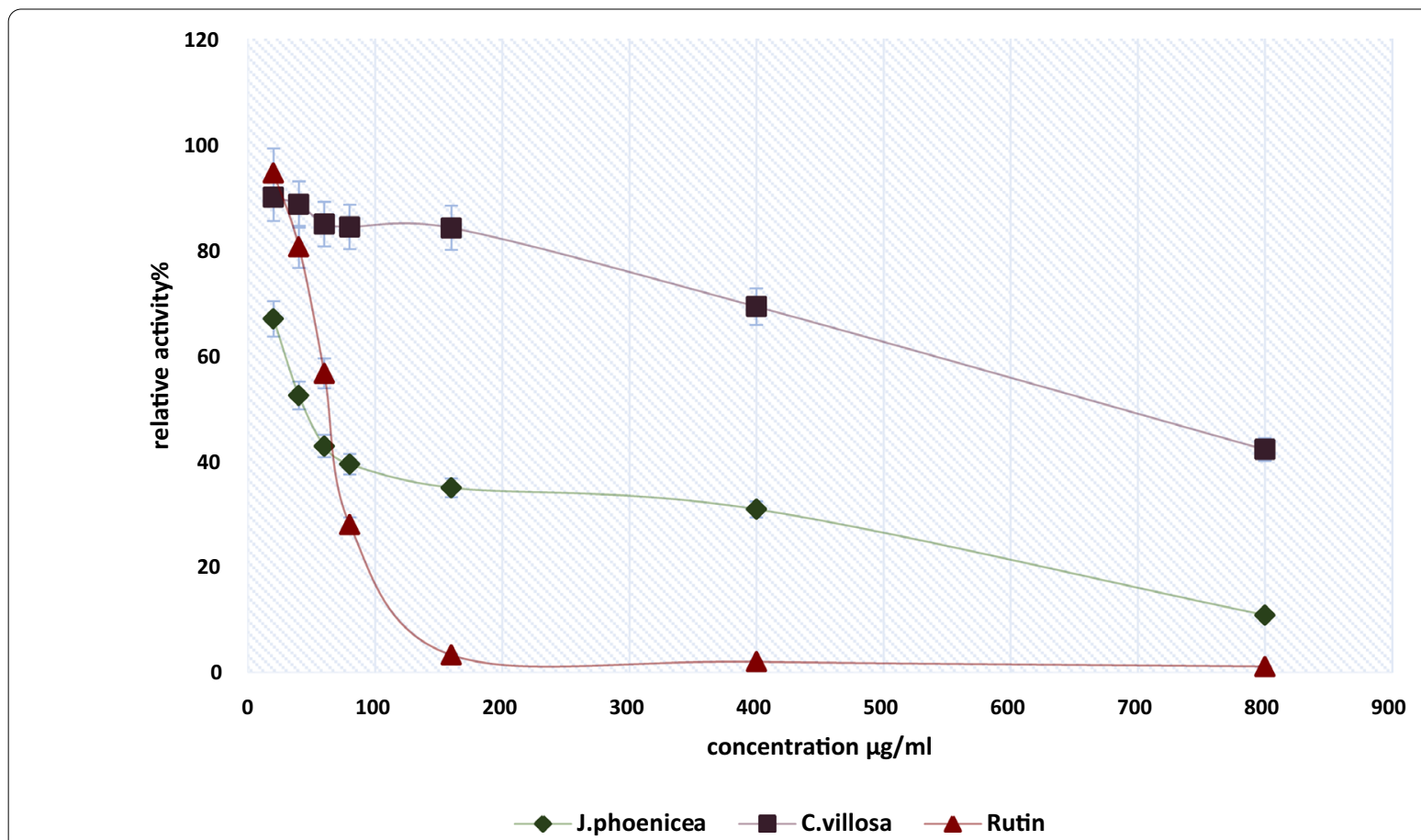

Fig. 3 Relative activity (\%) for $\beta$-galactosidase from A. oryzae in presence of J. phoenicea, C. villosa, and rutin, using ONPG as a substrate. Mean \pm SD $(n=3)$

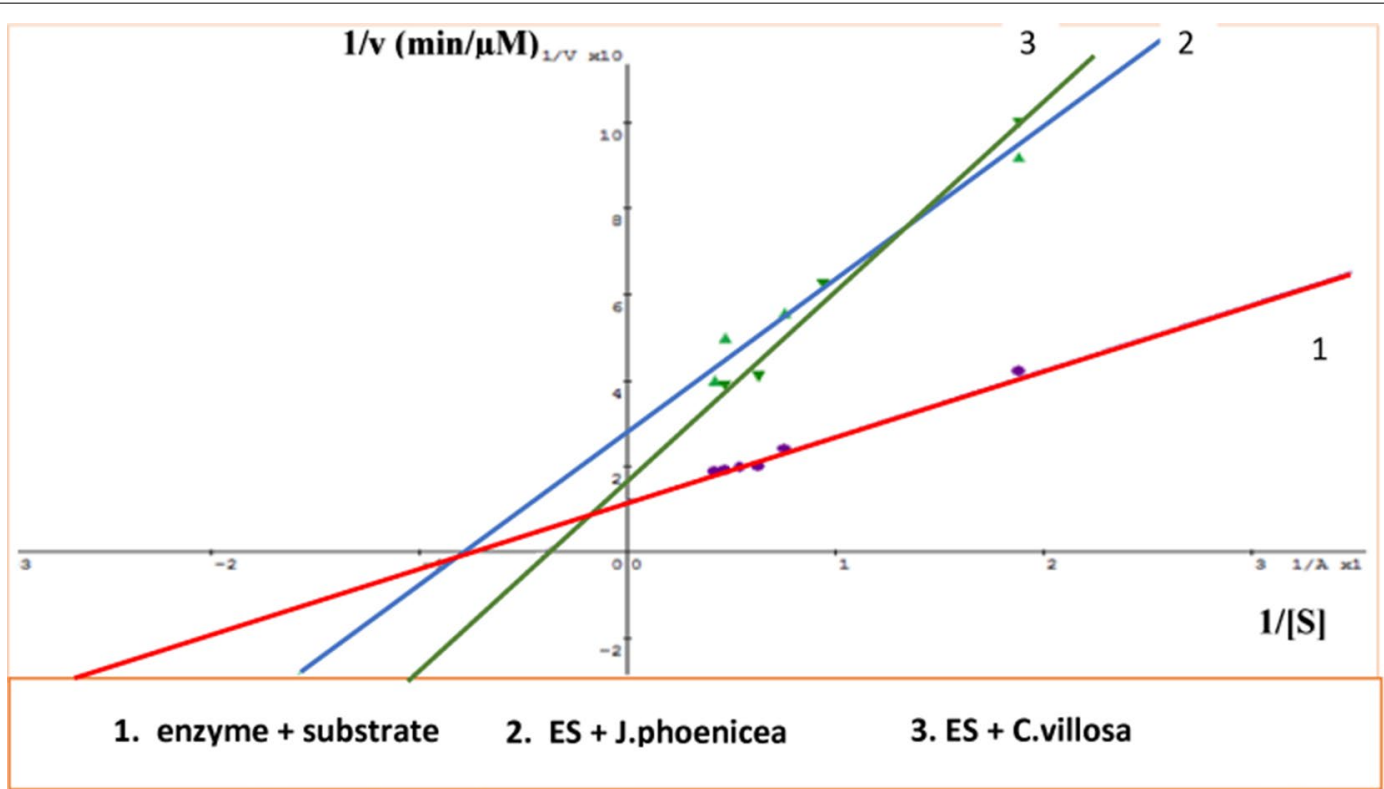

Fig. 4 Inhibition of $\beta$-galactosidase by J. phoenicea, AND C. villosa, in the presence of various concentrations of ONPG as a substrate. Mean \pm SD $(n=3)$

agreed with previous work [6,33, 47], which showed that methanol was a good solvent for the extraction of phenolic compounds from JP. It was documented that the highest phenolic content, for leaves and berries, was achieved by ethanol ( 35.4 and $35.8 \%$, respectively), followed by methanol (26.2 and $16.4 \%$, respectively) [6]. In this study, the total yield of methanol extracts of JP leaves was $22.83 \%$, which was analogous to that reported in [6]. 
Table 4 Kinetic values of $\beta$-galactosidase from A. oryzae in the presence of J. phoenicea and C. villosa extracts and Galactose

\begin{tabular}{lllll}
\hline Inhibitor & $\begin{array}{l}\text { Km } \\
(\mathbf{m M})\end{array}$ & $\begin{array}{l}\text { Vmax } \\
(\mathbf{m U})\end{array}$ & $\begin{array}{l}\text { Ki } \\
(\mathbf{m g} / \mathbf{m l})\end{array}$ & Mode of inhibition \\
\hline Control & $1.311 \pm 0.091^{\mathrm{a}}$ & $85.35 \pm 0.028^{\mathrm{a}}$ & 0 & Normal \\
J.phoenicea & $1.256 \pm 0.089^{\mathrm{a}}$ & $35.29 \pm 0.033^{\mathrm{b}}$ & $1.416 \pm 0.058$ & Non-competitive \\
C. villosa & $2.581 \pm 0.034^{\mathrm{b}}$ & $58.64 \pm 0.015^{\mathrm{c}}$ & $1.537 \pm 0.039$ & Mixed \\
Galactose & $2.770 \pm 0.072^{\mathrm{c}}$ & $55.55 \pm 0.024^{\mathrm{d}}$ & $1.866 \pm 0.052$ & Mixed \\
\hline
\end{tabular}

Results are means $\pm S D(n=3)$. Values in the same column with different letters differ significantly at $p<0.05$

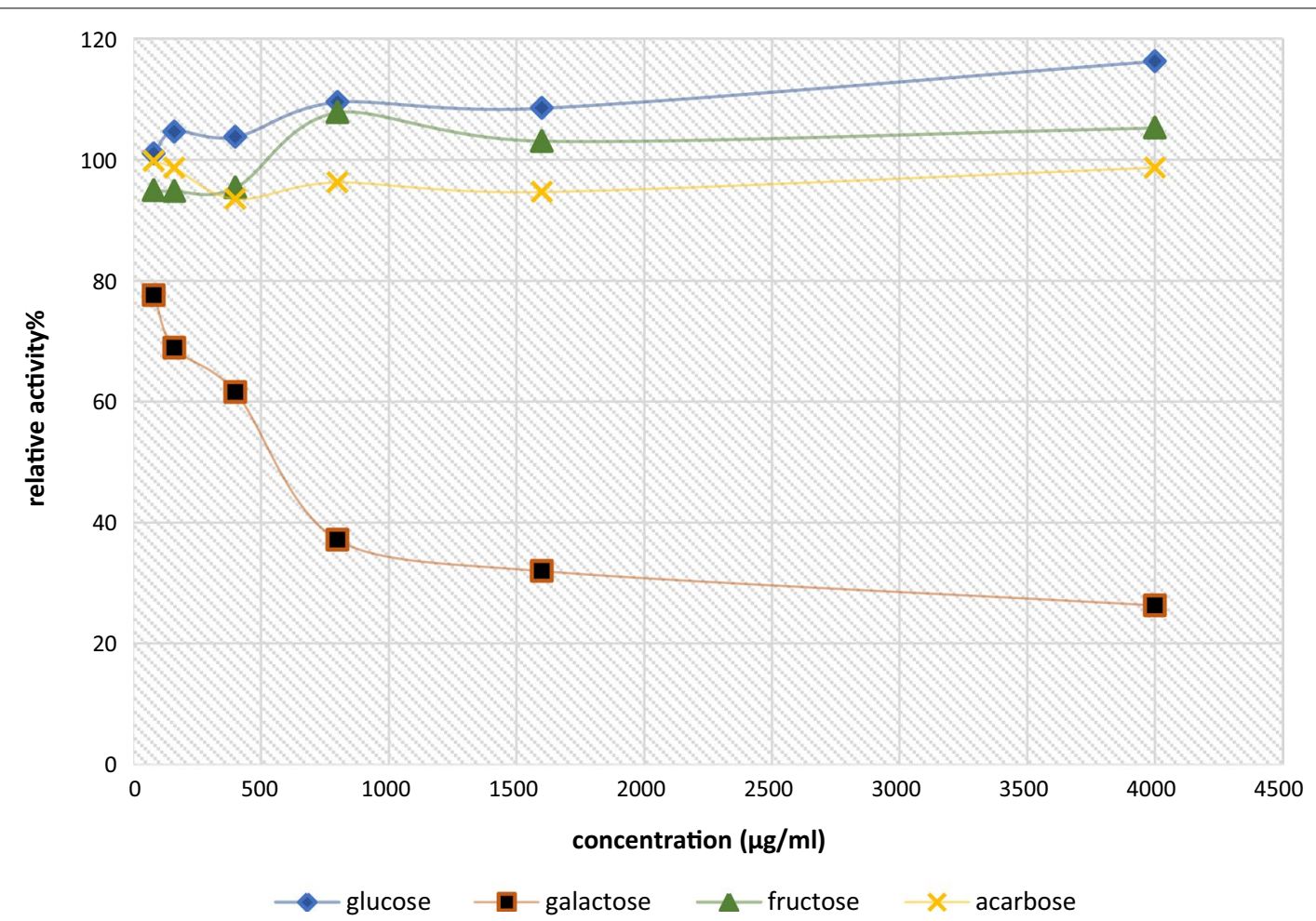

Fig. $5 \beta$-galactosidase relative activity in the presence of glucose, galactose, fructose and acarbose. Result expressed are mean of three independent experiments

Table 5 Kinetic and thermodynamic parameters of $\beta$-galactosidase inactivation

\begin{tabular}{llllllll}
\hline $\begin{array}{l}\text { Temp } \\
\left({ }^{\circ} \mathbf{C}\right)\end{array}$ & $\begin{array}{l}\text { Kd } \\
(\mathbf{m i n}-\mathbf{1})\end{array}$ & $\begin{array}{l}\mathbf{R 2} \\
(\mathbf{\%})\end{array}$ & $\begin{array}{l}\mathbf{t 1} \mathbf{2} \\
(\mathbf{m i n})\end{array}$ & $\begin{array}{l}\mathbf{D} \\
(\mathbf{m i n})\end{array}$ & $\begin{array}{l}\Delta \mathbf{H} \\
(\mathbf{k J} / \mathbf{m o l})\end{array}$ & $\begin{array}{l}\Delta \mathbf{G} \\
(\mathbf{k J} / \mathbf{m o l})\end{array}$ & $\begin{array}{l}\Delta \mathbf{S} \\
(\mathbf{J} /(\mathbf{m o l} . \mathbf{K}))\end{array}$ \\
\hline 50 & 0.0023 & 94.39 & 301.30 & 1001.12 & 121.84 & 91.026 & 95.37 \\
55 & 0.0064 & 96.49 & 108.28 & 359.78 & 121.80 & 89.644 & 98.00 \\
60 & 0.0123 & 81.88 & 56.34 & 187.20 & 121.76 & 89.201 & 97.74 \\
65 & 0.0862 & 98 & 8.04 & 26.71 & 121.72 & 85.068 & 108.39 \\
\hline
\end{tabular}

The total phenolic, flavonoids, and flavonols contents were higher in extract from leaves of JP than from CV. The variation in the phenolic yields between plant species as well as within the plant parts may be attributed to polarities of different compounds in the parts as well as to geographical location [48].

The amounts of total phenolics of both leaves of JP and $\mathrm{CV}$ were within the values ranged from $52 \pm 1$ to $217 \pm 2 \mathrm{~g} \mathrm{GAE} / \mathrm{kg}$ of dry material, previously reported 


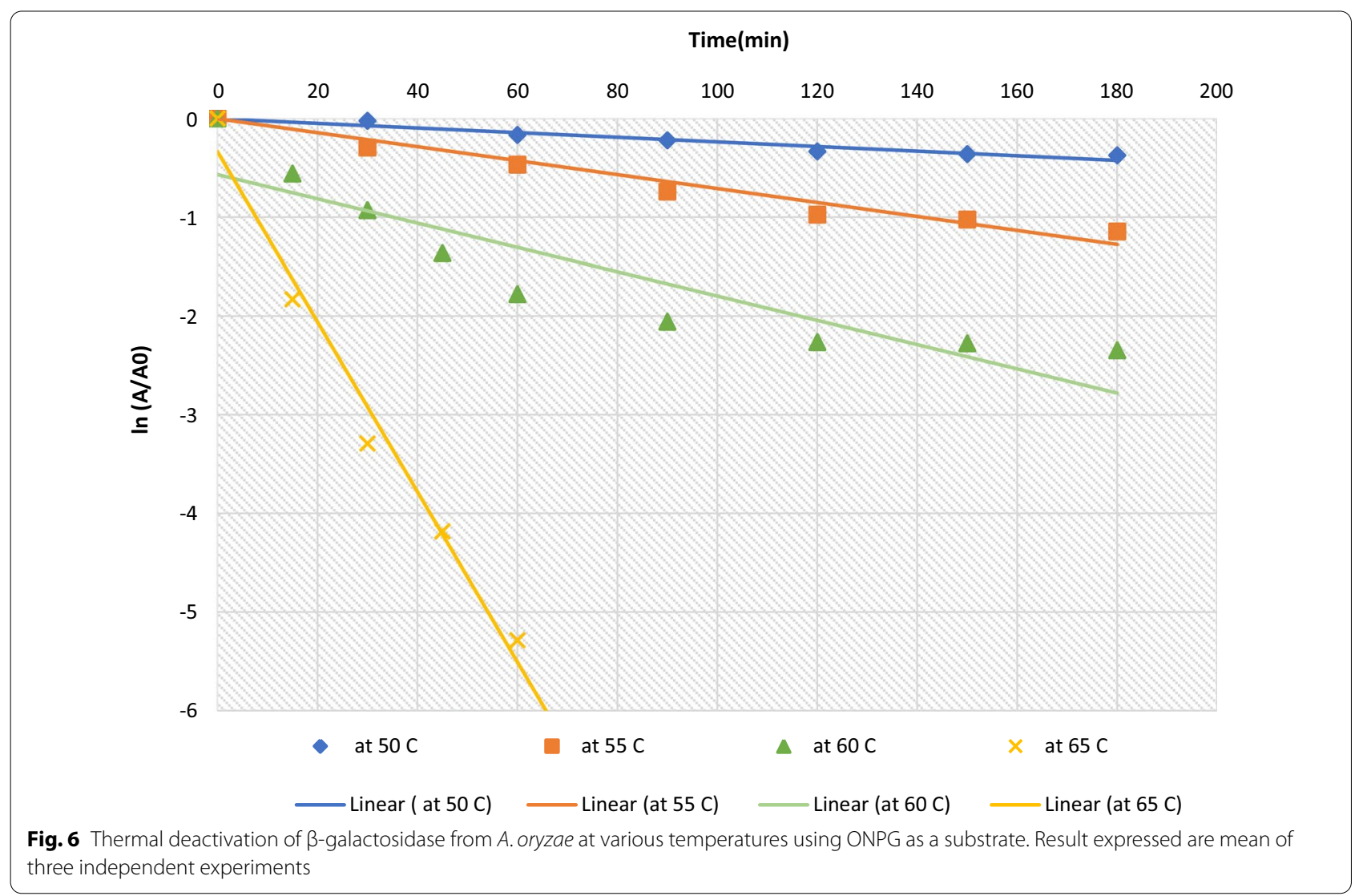

[6]. Consequently, the reporting of the high amount of phenols, flavonoids, and flavonols contents of JP leaves extracts could be used as an important species used in the food, and pharmaceutical industry.

The evaluation of different bioactivities of $J P$ and $\mathrm{CV}$ crude extracts revealed that the JP methanolic extract possessed a high scavenging capacity for the generated $\mathrm{DPPH}$ radical at $\left(\mathrm{IC}_{50}=11.10 \pm 0.015 \mu \mathrm{g} / \mathrm{mL}\right)$ than $\mathrm{CV}$ extract $\left(\mathrm{IC}_{50}=15.6 \pm 0.019 \mu \mathrm{g} / \mathrm{mL}\right)$. This could be attributed to significant amounts of flavonoids present in JP. DPPH radical scavenging of JP extract showed 10 times less efficacy to the gallic acid standard reference $\left(\mathrm{IC}_{50}=1.32 \pm 0.011\right)$. The antioxidant activity of JP and $\mathrm{CV}$ leaves was within the results shown in earlier literate $[6,49]$. The scavenging effect of the extracts against DPPH radicals and FRAP is related to the electron transfer/donating ability. Presence of flavonoids in JP and CV extracts as important phenolic compounds exert several antioxidant activities and ensuring free-radical scavenging activity and protection against oxidative stress [50]; it confirms the ability of both extracts from JP and CV to scavenge the DPPH radicals.

Furthermore, JP extract exerts a higher activity as antioxidant than CV extract in FRAP assay; it might be attributed to the high phenolic content of JP extract.
The availability of the phenolic hydrogens which behave as hydrogen donating radical scavengers can be easily predicted for antioxidant activity [51]. Therefore, polyphenols, depending on their precise structure and the proximity or adjacency of hydroxyl groups, have a metalchelating potential. Thus, polyphenols may have the possibility of chelating metal ions and preventing iron- and copper- to initiate radical species $[52,53]$. The reducing power of the extracts is consistent with the studies carried out on the aerial part of $A$. longa and $A$. indica [54$56]$, which indicated that they have a reducing power.

Diabetes is characterized by high blood sugar levels, which can lead to serious complications, so maintaining near-normal levels of glycemia is a goal of treating patients with diabetes [57]. The ability of JP and CV extracts to inhibit $\beta$-galactosidase in a concentration dependent manner might have a role in controlling blood glucose level. It was observed that the effect of JP extract was significantly higher than $\mathrm{CV}$ extract on the enzyme activity with $\mathrm{IC}_{50}=65 \mu \mathrm{g} / \mathrm{ml}$ compared to $700 \mu \mathrm{g} / \mathrm{ml}$, respectively. Previously it was reported that the more maceration of sample in polar solvents such as methanol, it will be a promising source for the reduction of postprandial glucose [57]. This finding is consistent with previous studies which demonstrated that 


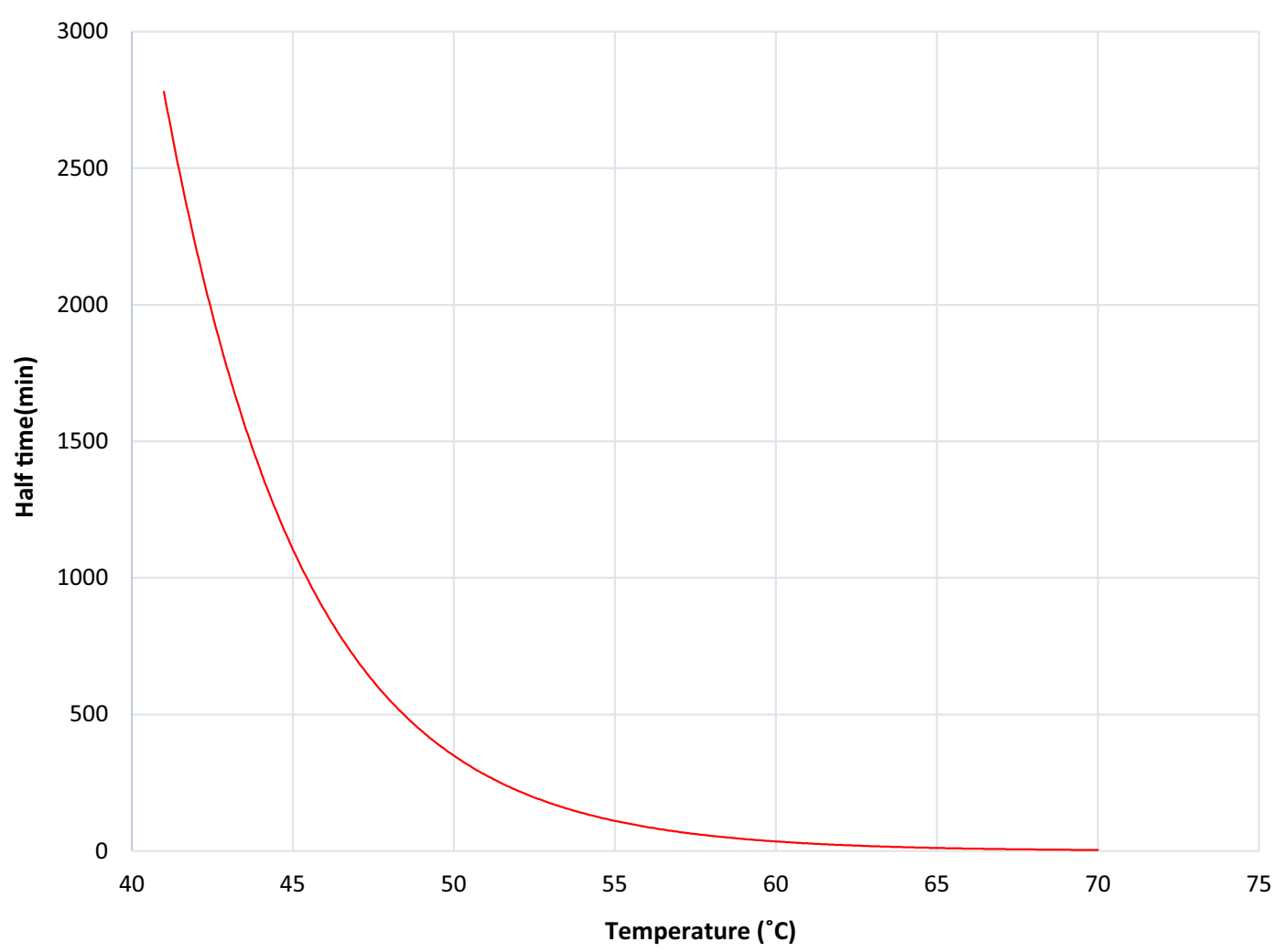

Fig. 7 Half-life of $\beta$-galactosidase from A. oryzae as influenced by temperatures

some medicinal plant extracts, such as $75 \%$ aqueous -methanolic extract of propolis, inhibit $\alpha$-glucosidase with an $\mathrm{IC}_{50}$ of $7.24 \pm 1.16 \mu \mathrm{g} / \mathrm{mL}$. The inhibitory effect of medicinal plants against $\beta$-Galactosidase activity showed various $\mathrm{IC}_{50}$ values range from $50 \mu \mathrm{g} / \mathrm{ml}$ to $5 \mathrm{mg} / \mathrm{ml}$ in different studies $[58,59]$. Moreover, it was documented that galactose has an inhibitory effect on the activity of $\beta$-Galactosidase $[60,61]$; a result which is on line with our finding on influence of galactose supplementation on the hydrolysis rate of the enzyme with $\mathrm{IC}_{50}$ of $600 \mu \mathrm{g} / \mathrm{ml}$.

The effect of glucose on $\beta$-Galactosidase, demonstrated significant activation of hydrolysis rate at concentrations exceeded $1.5 \mathrm{mg} / \mathrm{ml}$. This outcome confirms the hypothesis that glucose binds to the enzyme at a site other than the active one, in addition to affecting the affinity of the enzyme for the substrate [62]. Furthermore, the inability of fructose and acarbose to influence the enzyme catalytic activity was documented previously by different literatures [63].

As the kinetic parameters are important for studying $\beta$-Galactosidase enzyme behavior in presence of different factors, the mode of inhibition was obtained by a typical double reciprocal Lineweaver-Burk plot. Therefore, the results showed that the maximum velocity $\left(\mathrm{V}_{\max }\right)$ decreased in the presence of the extracts of JP as well as $\mathrm{CV}$ and galactose, but the $\mathrm{Km}$ increased by $\mathrm{CV}$ and galactose or slightly decreased by JP extract which indicating mixed inhibition and non-competitive inhibition, respectively. The mixed competitive inhibition indicates that the inhibitor can bind to the free enzyme or to the Enzyme-Substrate complex other than the catalytic site, which results in the decrease of Vmax [64]. Otherwise, a non-competitive inhibitor binds to a different site that may be a site other than the active site of the enzyme, due to a change in the chemical structure of the enzyme; therefore, it can block the binding of substrate or stopping of enzymatic activity. These results are consistent with previous studies that revealed inhibitory activity of galactose on $\beta$-Galactosidase enzyme [61].

To study the thermal stability of $\beta$-Galactosidase, the enzyme was tested at different temperatures (50 to $65^{\circ} \mathrm{C}$ ). Although $\beta$-Galactosidase was stable at $45^{\circ} \mathrm{C}$ during the test period $(3 \mathrm{~h})$, its activity decreased at temperatures $\geq 50{ }^{\circ} \mathrm{C}$. Inactivation of $\beta$-Galactosidase involves changing in the secondary, tertiary, or quaternary structure of a protein, without breaking covalent bonds [65]. The plots of residual activity vs. incubation time for the enzyme were linear, with $\mathrm{R}^{2}>81 \%$, which indicated that the inactivation could be expressed in terms of first-order 
kinetics in the temperature range of $50-65{ }^{\circ} \mathrm{C}$. The kinetic enzymatic modeling of thermal inactivation and the determination of its thermodynamic parameters were analyzed at changeable temperatures and various conditions by [66]. The determinations of half-life $\left(\mathrm{t}_{1 / 2}\right)$ are more accurate and reliable especially when computing the stability properties of an enzyme at different temperatures [67]. Thus, with increasing temperature, the $t_{1 / 2}$ and $\mathrm{D}$ values were decreased, while the first-order thermal deactivation rate constant $(\mathrm{kd})$ was increased. The results explored that the enzyme is less thermostable at higher temperatures, which led to a higher rate constant [68]. The $\mathrm{z}$ value of $\beta$-galactosidase, calculated from the slope of the graph between $\log \mathrm{D}$ vs. temperature, was $10{ }^{\circ} \mathrm{C}$. In general, the high magnitudes of $\mathrm{z}$-values mean more sensitivity to the duration of heat treatment and lower $\mathrm{z}$-values mean more sensitivity to increase in temperature [69].

The activation energy (Ed) of the thermal inactivation mechanism, which is the essential quantity to determine the thermodynamic parameters for thermal stability, is equal to $208.88 \mathrm{~kJ} \mathrm{~mol}^{-1}$ which is comparable to previous results on the inactivation of $\beta$-galactosidases from different strains of Streptococcus thermophilus and Lactobacillus bulgaricus; it was ranged from 200 to $215 \mathrm{~kJ} \mathrm{~mol}^{-1}$, indicating a high amount of activation energy needed to initiate denaturation of the enzyme [29]. Variations in activation enthalpy $(\Delta \mathrm{H})$, activation entropy $(\Delta S)$, and Gibbs free energy $(\Delta G)$ were calculated for the different temperatures as listed in Table 7 . Positive $\Delta H$ values indicate that enzyme inactivation is an endothermic process [70]. The high values of $\Delta \mathrm{H}^{\circ}$ resulted from the thermal inactivation of $\beta$-galactosidase which indicates that the enzymatic activity undergoes a considerable change in conformation during denaturation [71]. The fact that the $\Delta \mathrm{H}^{\circ}$ value decreases with the increase in temperature reveals that less energy is required to denature the enzyme at high temperatures [72]. When entropy of inactivation $\left(\Delta \mathrm{S}^{\circ}\right)$ was calculated at each temperature, it showed positive values, which indicates that there is an increase in the molecule randomness or disorder during the exposure to high temperatures. In contrast, negative $\Delta S$ values are expected for an aggregation process in which a few intermolecular bonds are formed [73]. Whilst the positive $(\Delta G)$ values indicate that the inactivation of the enzyme is not a spontaneous reaction. In the present study, there was a decrease in $\Delta G$ values with increasing temperatures, which is an indication that the destabilization of the enzyme molecule is more spontaneous and faster [74], however, a lower $\Delta G^{\circ}$ values than the $\Delta \mathrm{H}^{\circ}$ values is due to the positive entropic contribution during the inactivation process.

\section{Conclusion}

The medicinal plants encompass natural products such as phytochemicals, used in several medical applications as anticancer, antidiabetic, and antioxidant agents. Traditionally, leaf extracts of JP and CV are considered as promising natural medicinal agents and widely used for the treatment of diabetes mellitus. In addition, the ability of JP and CV extracts to modulate oxidative stress in the body indicated their role in competing the progress of several metabolic diseases such as diabetes mellitus. Furthermore, oral consumption of plants stimulates excretion or decreases the digestion of carbohydrates by inhibiting carbohydrate catalytic enzymes such as $\beta$-galactosidase; the enzyme responsible for the metabolism of carbohydrates into glucose in the digestive tract. All these activities may be attributed to the high polyphenolic contents of JP and CV. This work demonstrates the value of JP and $\mathrm{CV}$ as sources of metabolites with relevant pharmaceutical potential and essential to better retain enzymatic activity in food biotechnology and products supplemented with heat-sensitive enzymes and to reduced glucose levels.

\section{Abbreviations \\ $\mathrm{IC}_{50}$ : The half-maximal inhibitory concentration; DPPH: 1,1-Diphenyl,2-picryl- hydrazyl; FRAP: Ferric reducing antioxidant power; GAE: Gallic acid equivalent; RE: Rutin equivalent; $\Delta H$ : Enthalpy change.}

\section{Acknowledgements}

This work was carried out at the Department of Biology, Mutah University, Karak, Jordan.

\section{Authors' contributions}

AA has designed the study, wrote the manuscript, and contributed to results analysis. MA1 has contributed to the major bench experiments as well as results analysis. MA2 and FA equally edit the manuscript.

Funding

Not applicable.

Availability of data and materials

The datasets used and/or analysed during the current study available from the corresponding author on reasonable request.

\section{Declarations}

Ethics approval and consent to participate

Not applicable.

Human and animal rights

No animals/humans were used in the current research.

Consent for publication

Not applicable.

Competing interests

The authors declare no conflict of interest. 


\section{Author details}

1 Department of Biological Sciences, Faculty of Science, Mutah University, Mutah, P.O. Box 7, Karak 61710, Jordan. ${ }^{2}$ Chemistry Department, College of Science, Imam Abdulrahman Bin Faisal University, Dammam, Saudi Arabia.

\section{Received: 9 February 2021 Accepted: 24 September 2021} Published online: 04 October 2021

\section{References}

1. Bansode TS, Salalkar BK. Phytotherapy: herbal medicine in the management of Diabetes mellitus. Plant Sci Today. 2017:4(4):161-5.

2. Shakya AK. Medicinal plants: future source of new drugs. Int J Herb Med. 2016:4(4):59-64

3. Angioni A, Barra AT, Russo M, Coroneo V, Dessí S, Cabras P. Chemical composition of the essential oils of Juniperus from ripe and unripe berries and leaves and their antimicrobial activity. J Agric Food Chem. 2003;51(10):3073-8.

4. Aboul-Ela M, El-Shaer N, El-Azim TA. Chemical constituents and hypoglycemic effect of Juniperus phoenicea: part I. Alex J Pharm Sci. 2005;19(2):109-16.

5. Oboh G, Ademiluyi AO, Akinyemi AJ, Henle T, Saliu JA, Schwarzenbolz $U$. Inhibitory effect of polyphenol-rich extracts of jute leaf (Corchorus olitorius) on key enzyme linked to type 2 diabetes (a-amylase and a-glucosidase) and hypertension (angiotensin I converting) in vitro. J Funct Foods. 2012;4(2):450-8.

6. Ennajar M, Bouajila J, Lebrihi A, Mathieu F, Abderraba M, Raies A, Rom dhane M. Chemical composition and antimicrobial and antioxidant activities of essential oils and various extracts of Juniperus phoenicea L. (Cupressacees). J Food Sci. 2009:74(7):M364-71.

7. Al-Mustafa AH, Al-Thunibat OY. Antioxidant activity of some Jordanian medicinal plants used traditionally for treatment of diabetes. PJBS. 2008;11(3):351-8.

8. Adams RP. Junipers of the world: the genus Juniperus. 2nd ed. Vancouver: Trafford Publishing Company; 2008

9. Al-Qura'n S. Ethnopharmacological survey of wild medicinal plants in Showbak, Jordan. J Ethnopharmacol. 2009;123:45-50.

10. Abu-Darwish MS, Gonçalves MJ, Cabral C, Cavaleiro C, Salgueiro L. Chemical composition and antifungal activity of essential oil from Juniperus phoenicea subsp. phoenicea berries from Jordan. Acta Aliment Hung. 2013;42(4):504-11.

11. Ali SA, Rizk MZ, Ibrahim NA, Abdallah MS, Sharara HM, Moustafa MM. Protective role of Juniperus phoenicea and Cupressus sempervirens against CCI4. World J Gastrointest Pharmacol Ther. 2010;1 (6):123-31.

12. Onais EY, Abdulla FA, Abu Ghalyun YY. Antidiarrheal effects of Juniperusphoenicia L. leaves extract in rats. Pak J Biol Sci. 2005;8(6):867-71.

13. Barrero AF, Herrador MM, Arteaga P, Quílez deloral JF, Sanchez-Fernandez E, Akssira M, Akkad S. Chemical composition of the essential oil from the leaves of Juniperus phoenicea L. from North Africa. J Essential Oil Res. 2006;18(2):168-9.

14. Hoferl M, Stoilova I, Schmidt E, Wanner J, Jirovetz L, Trifonova D, Krastev $L$, Krastanov A. Chemical Composition and antioxidant properties of juniper berry (Juniperus communis L.) essential oil action of the essential oil on the antioxidant protection of Saccharomyces cerevisiae model organism. Antioxidants (Basel). 2014;3(1):81-98.

15. Pepeljnjak S, Kosalec I, Kalodera Z, Blazevic N. Antimicrobial activity of juniper berry essential oil (Juniperus communis L., Cupressaceae). Acta Pharma. 2005:55:417-22

16. Gordien AY, Gray Al, Franzblau SG, Seidel V. Antimycobacterial terpenoids from Juniperus communis L. (Cuppressaceae). J Ethnopharmacol. 2009:126:500-5.

17. Ju JB, Kima JS, Choi CW, Lee HK, Oha TK, Kima SC. Comparison between ethanolic and aqueous extracts from Chinese juniper berries for hypoglycaemic and hypolipidemic effects in alloxan-induced diabetic rats. J Ethnopharmacol. 2008;11591:110-5.

18. Loy G, Cottiglia F, Garau D, Deidda D, Pompei R, Bonsignore L. Chemical composition and cytotoxic and antimicrobial activity of Calycotome villosa (Poiret) link leaves. Farmaco. 2001;56(5-7):433-6.

19. Lyoussi B, Cherkaoui Tangi K, Morel N, Haddad M, Quetin-Leclercq J. Evaluation of cytotoxic effects and acute and chronic toxicity of aqueous extract of the seeds of Calycotome villosa (Poiret) Link (subsp. intermedia) in rodents. Avicenna J Phytomed. 2018;8(2):122-35.

20. Hartwell JL. Plants used against cancer. A survey. Lloydia. 1971;34(2):204-55

21. Elkhamlichi A, El Antri A, El Hajaji H, El Bali B, Oulyadi H, Lachkar M. Phytochemical constituents from the seeds of Calycotome villosa subsp. intermedia. Arab J Chem. 2017:10:S3580-3.

22. El Antri A, Messouri I, Tlemçani R, Bouktaib M, El Alami R, El Bali B, Lachkar M. Flavone glycosides from Calycotome villosa subsp. intermedia. Molecules. 2004;9(7):568-73.

23. Pistelli L, Fiumi C, Morelli I, Giachi I. Flavonoids from Calicotome villosa. Fitoterapia. 2003;74(4):417-9.

24. Alhage J, Elbitar H, Taha S, Guegan JP, Dassouki Z, Vives T, Benvegnu T. Isolation of bioactive compounds from Calicotome villosa stems. Molecules. 2018;23(4):851.

25. El Antri A, Lachkar N, El Hajjaji H, Gaamoussi F, Lyoussi B, El Bali B, Lachkar M. Structure elucidation and vasodilator activity of methoxy flavonols from Calycotome villosa subsp. inter-media. Arab J Chem. 2010;3(3):173-8.

26. Bailes BK. Diabetes mellitus and its chronic complications. AORN J. 2002;76(2):265-82.

27. Li PH, Lin YW, Lu WC, Hu JM, Huang DW. In vitro hypoglycemic activity of the phenolic compounds in longan fruit (Dimocarpus Longan var. Fen ke) shell against a-glucosidase and $\beta$-galactosidase. Int J Food Prop. 2016:19(8):1786-97.

28. Boon MA, Janssen AEM, Van't Riet K. Effect of temperature and enzyme origin on the enzymatic synthesis of oligosaccharides. Enzyme Microb Technol. 2000:26(24):271-81.

29. Ustok Fl, Tari C, Harsa S. Biochemical and thermal properties of $\beta$-galactosidase enzymes produced by artisanal yoghurt cultures. Food Chem. 2010;119(3):1114-20.

30. Kumaran A, Karunakaran RJ. In vitro antioxidant activities of methanol extracts of five Phyllanthus species from India. LWT-Food Sci Technol. 2007:40(2):344-52.

31. Harborne AJ. Phytochemical methods a guide to modern techniques of plant analysis. 3rd ed. Springer Netherlands; 1998.

32. Morsy N. Phytochemical analysis of biologically active constituents of medicinal plants. Main Group Chem. 2014;13(1):7-21.

33. Velioglu YS, Mazza G, Gao L, Oomah BD. Antioxidant activity and total phenolic in selected fruits, vegetables, and grain products. J Agricult Food Chem. 1998:46(10):4113-7.

34. Zhishen J, Mengcheng T, Jianming W. The determination of flavonoid contents in mulberry and their scavenging effects on superoxide radicals. Food Chem. 1999;64(4):555-9.

35. Abdel-Hameed ESS. Total phenolic contents and free radical scavenging activity of certain Egyptian Ficus species leaf samples. Food Chem. 2009;114(4):1271-7.

36. Deng J, Cheng W, Yang G. A novel antioxidant activity index (AAU) for natural products using the DPPH assay. Food Chem. 2011;125(4):1430-5.

37. Benzie IF, Strain JJ. The ferric reducing ability of plasma (FRAP) as a measure of "antioxidant power": the FRAP assay. Anal Biochem. 1996;239(1):70-6.

38. Tanaka Y, Kagamiishi A, Kiuchi A, Horiuchi T. Purification and properties of B-galactosidase from Aspergillus oryzae. J Biochem. 1975;77(1):241-7.

39. Lineweaver $\mathrm{H}$, Burk D. The determination of enzyme dissociation constants. J Am Chem Soc. 1934;56(3):658-66.

40. Cavalcante Braga AR, Manera AP, da Costa OJ, Sala L, Maugeri F, Juliano KS. Kinetics and thermal properties of crude and purified $\beta$-galactosidase with potential for the production of galactooligosaccharides. Food Technol Biotechnol. 2013;51(1):45-52.

41. Sõukand R, Pieroni A, Biró M, Dénes A, Dogan $Y$, Hajdari A, Kalle R, Reade $B$, Mustafa B, Nedelcheva A, Quave CL, Łuczaj Ł. An ethnobotanical perspective on traditional fermented plant foods and beverages in Eastern Europe. J Ethnopharmacol. 2015;170:284-96.

42. Lantto TA, Colucci M, Zavadova V, Hiltunen R, Raasmaja A. Cytotoxicity of curcumin, resveratrol and plant extracts from basil, juniper, laurel and parsley in SH-SY5Y and CV1-P cells. Food Chem. 2009;117:405-11.

43. Cao X, Zou H, Cao J, Cui Y, Sun S, Ren K, Song Z, Li D, Quan M. A candidate Chinese medicine preparation-Fructus Viticis Total Flavonoids inhibits stem-like characteristics of lung cancer stem-like cells. BMC Complement Altern Med. 2016;16:364. 
44. Soobrattee MA, Neergheen VS, Luximon-Ramma A, Aruoma O, Bahorun T. Phenolics as potential antioxidant therapeutic agents: mechanism and actions. Mut Res. 2005;579:200-13.

45. Höferl M, Stoilova I, Schmidt E, Wanner J, Jirovetz L, Trifonova D, Krastev L, Krastanov A. Chemical composition and antioxidant properties of juniper berry (Juniperus communis L.) essential oil. Action of the essential oil on the antioxidant protection of Saccharomyces cerevisiae model organism. Antioxidants. 2014;3(1):81-98.

46. Ju JB, Kima JS, Choi CW, Lee HK, Oha TK, Kima SC. Comparison between ethanolic and aqueous extracts from Chinese juniper berries for hypoglycaemic and hypolipidemic effects in alloxan-induced diabetic rats. J Ethnopharmacol. 2008;115:110-5.

47. Rababah TM, Banat F, Rababah A, Ereifej K, Yang W. Optimization of extraction conditions of total phenolics, antioxidant activities, and anthocyanin of oregano, thyme, terebinth, and pomegranate. J Food Sci. 2010;75(7):C626-32

48. Jayaprakasha GK, Singh RP, Sakariah KK. Antioxidant activity of grape seed (Vitis vinifera) extracts on peroxidation models in vitro. Food Chem. 2001;73:285-90.

49. Hayouni EA, Abedrabba M, Bouix M, Hamdi M. The effects of solvents and extraction method on the phenolic contents and biological activities in vitro of Tunisian Quercus coccifera L. and Juniperus phoenicea L. fruit extracts. Food Chem. 2007;105:1126-34.

50. Seyoum A, Asres K, El-Fiky FK. Structure-radical scaveng-ing activity relationships of flavonoids. Phytochemistry. 2006;67(18):2058-70.

51. Rice-Evans CA, Miller NJ, Paganga G. Structure-antioxidant activity relationships of flavonoids and phenolic acids. Free Radic Biol Med. 1996;20(7):933-56.

52. Laughton MJ, Evans PJ, Moroney MA, Hoult JRS, Hallowell B. Inhibition of mammalian 5-lipoxygenase and cyclo-oxygenase by flavonoids and phenolic dietary additives: relationship to antioxidant activity and to iron ion-reducing ability. Biochem Pharmacol. 1991;42(9):1673-81.

53. Morel I, Lescoat G, Cogrel P, Sergent O, Pasdeloup N, Brissot P, Cillard P, Cillard J. Antioxidant and iron-chelating activities of the flavonoids catechin, quercetin and diosmetin on iron-loaded rat hepatocyte cultures. Biochem Pharmacol. 1993:45(1):13-9.

54. Merouani N, Belhattab R, Sahli F. Evaluation of the biological activity of Aristolochia longa I. Extracts. Int J Pharm Sci Res. 2017;8(5):1978-92.

55. Subramaniyan V, Saravanan R, Baskaran D, Ramalalingam S. In vitro free radical scavenging and anticancer potential of aristolochia indica $\mathrm{L}$ Against MCF-7 cell line. Int J Pharm Pharm Sci. 2015;7(6):392-6.

56. Nile SH, Nile AS, Keum YS. Total phenolics, antioxidant, antitumor, and enzyme inhibitory activity of Indian medicinal and aromatic plants extracted with different extraction methods. 3 Biotech. 2017;7(1):76.

57. Marles RJ, Farnsworth NR. Antidiabetic plants and their active constituents. Phytomedicine. 1995:2(2):137-89.

58. Shalaby NM, Abd-Alla HI, Aly HF, Albalawy MA, Shaker KH, Bouajila J. Preliminary in vitro and in vivo evaluation of antidiabetic activity of Ducrosia anethifolia Boiss. and its linear furanocoumarins. BioMed Res Int 2014; 2014: 480545

59. El Omari N, Sayah K, Fettach S, El Blidi O, Bouyahya A, Faouzi MEA, Kamal $\mathrm{R}$, Barkiyou M. Evaluation of in vitro antioxidant and antidiabetic activities of Aristolochia longa extracts. Evid Based Complement Altern Med. 2019;2019(2019):1-9.

60. Shukla H, Chaplin M. No competitive inhibition of $\beta$-galactosidase ( $A$. oryzae) by galactose. Enzyme Microb Technol. 1993;15(4):297-9.

61. Portaccio M, Stellato S, Rossi S, Bencivenga U, Eldin MM, Gaeta FS, Mita DG. Galactose competitive inhibition of $\beta$-galactosidase (Aspergillus oryzae) immobilized on chitosan and nylon supports. Enzyme Microb Technol. 1998;23(1-2):101-6.

62. Vera C, Guerrero C, Illanes A. Determination of the transgalactosylation activity of Aspergillus oryzae $\beta$-galactosidase: effect of $\mathrm{pH}$, temperature, and galactose and glucose concentrations. Carbohyd Res. 2011;346(6):745-52

63. Lee SB, Park KH, Robyt JF. Inhibition of $\beta$-glycosidases by acarbose analogues containing cellobiose and lactose structures. Carbohyd Res. 2011;331(1):13-8.

64. Saboury AA. Enzyme inhibition and activation: a general theory. J Iran Chem Soc. 2009;6:219-29

65. Naidu GSN, Panda T. Studies on $\mathrm{pH}$ and thermal deactivation of pectolytic enzymes from Aspergillus niger. Biochem Eng J. 2003;16(1):57-67.

66. Klein MP, Sant'Ana V, Hertz PF, Rodrigues RC, Ninow JL. Kinetics and thermodynamics of thermal inactivation of $\beta$-galactosidase from Aspergillus oryzae. Braz Arch Biol Technol. 2018;61:e18160489.

67. Pal A, Khanum F. Characterizing and improving the thermostability of purified xylanase from Aspergillus niger DFR-5 grown on solid-statemedium. J Biochem Technol. 2010;2(4):203-9.

68. Marangoni AG. Characterization of enzyme stability. Enzyme Kinet Mod Approach. 2003;244:140-57.

69. Tayefi-Nasrabadi H, Hoseinpour-fayzi MA, Mohasseli M. Effect of heat treatment on lactoperoxidase activity in camel milk: a comparison with bovine lactoperoxidase. Small Rumin Res. 2011;99(2-3):187-90.

70. de Araújo VD, de Albuquerque LC, Neves RP, Mota CS, Moreira KA, de Lima-Filho JL, Cavalcanti MT, Converti A, Porto AL. Production and stability of protease from Candida buinensis. Appl Biochem Biotechnol. 2010;162(3):830-42.

71. Marin E, Sanchez L, Perez MD, Puyol P, Calvo M. Effect of heat treatment on bovine lactoperoxidase activity in skim milk: kinetic and thermodynamic analysis. J Food Sci. 2006;68(1):89-93.

72. Bhatti HN, Zia A, Nawaz R, Sheikh MA, Rashid MH, Khalid AM. Effect of copper ions on thermal stability of glucoamylase from Fusarium sp. Int J Agric Biol. 2005;7(4):585-7.

73. Anema SG, McKenna AB. Reaction kinetics of thermal denaturation of whey proteins in heated reconstituted whole milk. J Agric Food Chem. 1996:44(2):422-8.

74. Riaz M, Perveen R, Javed MR, Nadeem H, Rashid MH. Kinetic and thermodynamic properties of novel glucoamylase from Humicola sp. Enzyme Microb Technol. 2007;41(5):558-64.

\section{Publisher's Note}

Springer Nature remains neutral with regard to jurisdictional claims in published maps and institutional affiliations.

Ready to submit your research? Choose BMC and benefit from

- fast, convenient online submission

- thorough peer review by experienced researchers in your field

- rapid publication on acceptance

- support for research data, including large and complex data types

- gold Open Access which fosters wider collaboration and increased citations

- maximum visibility for your research: over $100 \mathrm{M}$ website views per year

At $\mathrm{BMC}$, research is always in progress.

Learn more biomedcentral.com/submissions 